\title{
ODPOWIEDZIALNOŚĆ KOŚCIOŁA ZA DAR ZBAWIENIA
}

Teologia moralna po Soborze Watykańskim II stanęła wobec, choć nieokreślonego, wezwania. Skoro Ojcowie Soborowi nie przyjęli traktatu dotyczącego teologii moralnej, trzeba więc było tworzyć, niemal intuicyjnie, nowe ujęcie całej teologii moralnej, a wskazówki dokumentów soborowych miały charakter ogólny dotyczący teologii jako takiej. Tu ujawniała się intuicja Ks. Prof. Stanisława Olejnika, by wyszukać przełomowe sugestie i według nich tworzyć nową koncepcję ujęcia moralności chrześcijańskiej. Ks. Olejnik skoncentrował się na wskazaniach Deklaracji o formacji kapłańskiej i z nich odczytał, w odnowionej teologii, główne przesłanie dla teologii moralnej: „Szczególną troskę należy skierować ku udoskonaleniu teologii moralnej, której naukowy wykład karmiony w większej mierze nauką Pisma świętego niech ukazuje wzniosłość powołania wiernych w Chrystusie i ich obowiązek przynoszenia owocu w miłości za życie świata" (DFK 16).

Owocem tych wysiłków naukowych jest książka, która stała się podręcznikiem teologii moralnej: Wodpowiedzi na dar i powołanie $B o \dot{z} e^{1}$. Kolejna wersję tej publikacji ks. Olejnik ujął w trzech tomach,

1 S. Ole j n i k, Wodpowiedzi na dar i powołanie Boże. Zarys Teologii moralnej, Warszawa 1979. 
w duchu ujęcia: Dar - Wezwanie - Odpowiedź2. Słowa te stały się kluczem - paradygmatem w odczytywaniu zagadnień moralności chrześcijańskiej w perspektywie historiozbawczej. By wezwania i odpowiedzi o charakterze moralnym nie stały się prostym moralizmem, trzeba właściwie odczytać fundament moralności chrześcijańskiej, czyli uprzedni dar zbawczej miłości Boga. Jeśli Kościół będzie świadomy wielkiego obdarowania zbawieniem, to czymś naturalnym stanie się chęć podjęcia Bożego wezwania do wymagań moralnych i podjęcia należnych odpowiedzi w codziennym życiu. Dla przykładu: jeśli Kościół jest zbawczym darem Boga, to powinien przyjąć wezwanie i szukać form odpowiedzi moralnych, by ów dar zachować i nim się dzielić.

Kościół, jako wspólnota zbawionych, zakorzeniony jest w Bogu Trójjedynym, dlatego wymiar trynitarny jest jego wymiarem podstawowym. Objawienie ukazuje Kościół w świetle odwiecznego planu „zrodzonego w sercu Ojca”, który realizował się w historii zbawienia. Kościół ujawnia bowiem tajemniczy plan Boga wobec ludzi (Ef 3, 9-11). Istotną treścią tego planu było nawiązanie więzów głębokiej miłości między Bogiem a ludzkością, czyniących z ludzkości Bożą rodzinę ${ }^{3}$ Ten Boży plan został zakłócony przez grzech pierworodny człowieka, powodujący rozbicie i podziały. Bóg pozostaje jednak wierny pierwotnemu zamysłowi miłości i zamierzał ukształtować ludzką wspólnotę na fundamencie dzieła odkupienia, którego celem jest przywrócenie utraconej jedności.

Kościół, zapowiedziany w figurach już od początku świata, przygotowany w historii narodu izraelskiego i w Starym Przymierzu, stanowi zapowiedź przyszłej wspólnoty zbawienia związanej z osobą

2 Tenże, Teologia moralna fundamentalna, Włocławek 1998; Tenże, Teologia moralna życia osobistego, Włocławek 1999; Tenże, Teologia moralna życia społecznego, Włocławek 2000.

3 Por. KKK 759. Por. także: S. N a g y, Kościót Ojca, Syna i Ducha Świętego, w: Katechizm Kościoła Katolickiego. Wprowadzenie, M. R u s e c k i, E. P u d e ł k o (red.), Lubin 1995, s. 116; T. F e d e r i c i, Pneumatologiczne podstawy misji, w: S. K a r o t e m p l e r (red.), A. H a 1 e $\mathrm{m}$ b a (red. wyd. pol.), Kościót misyjny. Podstawowe studium misjologii, (tłum. R. Dziura, A. Halemba), Warszawa 1997 s. 74-76. 
Mesjasza-Zbawiciela. Kościół - jako uczestnik uniwersalnego planu odkupienia w Jezusie Chrystusie - znajduje swoje urzeczywistnienie: „w przedwiecznym Bożym zamyśle Kościół jako zjednoczenie ludzi w Chrystusie-Głowie zostaje włączony w plan ogarniający całe stworzenie, plan - rzec można - kosmiczny: zjednoczyć wszystko w Chrystusie-Głowie"4.

Wypełniając odwieczny plan Ojca, Chrystus zapoczątkował królestwo niebieskie na ziemi głosząc Ewangelię i wzywając do wiary i nawrócenia $(\mathrm{Mk} 1,15)$. Jezus Chrystus powołał do istnienia Kościól, aby w nim i przez niego trwało i rozwijało się królestwo Boże w dziejach człowieka ${ }^{5}$. Początek Kościoła stanowiła grupa dwunastu Apostołów jako symbol dwunastu pokoleń Izraela i spełnienie obietnicy z czasów mesjańskich dotyczącej powstania nowego ludu Bożego. Kościół narodził się ostatecznie na fundamencie dzieła zbawczego Chrystusa: męki, śmierci i zmartwychwstania. Chrystus, powierzając Apostołom zadanie gromadzenia ludzi w jedności wiary, budował Kościół jako nową wspólnotę zbawienia ${ }^{6}$. Po Wniebowstąpieniu grupa uczniów Chrystusa trwała w oczekiwaniu na Ducha Świętego-Pocieszyciela, by Jego mocą świadczyć o wydarzeniach zbawczych.

W dniu Pięćdziesiątnicy Duch Święty napełnił życiem Bożym Apostołów i wszystkich wierzących oraz dał początek misji Kościoła? Zesłanie Ducha Świętego sprawiło, że Kościół ukazał się publicznie

4 J a n P a w e łII, Katecheza: Kościół w odwiecznym zamyśle Ojca (31.07.1991) nr 3, w: J a n P a w e ł II, Katechezy Ojca Świętego Jana Pawła II. Kościót, Kraków-Ząbki 1999, s. 21; por. S. O 1 e j n i k, Teologia moralna fundamentalna, dz. cyt., s. 93-94.

5 Por. KKK 763. Por. także: S. N a g y, Kościół Ojca, Syna i Ducha Świętego, w: Katechizm Kościoła Katolickiego. Wprowadzenie, dz. cyt., s. 117; S. K a ro t e m p r e 1, Chrystologiczne i soteriologiczne podstawy misji, w: Kościół misyjny, dz. cyt., s. 57-71.

${ }^{6}$ Por. Ja n P aw eł II, Katecheza: Jezus Chrystus - założyciel Kościoła (11.09.1991) nr 3, w: J a n P a w e ł II, Katechezy Ojca Świętego..., dz. cyt., s. 3233; KKK 765.

7 Por. Jan Paweł II, Katecheza: Duch Święty u początków Kościoła (2.10.1991) nr 4, w: Katechezy Ojca Świętego..., dz. cyt., s. 43-44; KKK 767. Por. także: T. F e d e r i c i, Pneumatologiczne podstawy misji, dz. cyt., s. 78. 
światu i zaczął głosić Ewangelię wobec narodów. Rozpoczął się także proces jednoczenia ludów i narodów w Kościele Nowego Przymierza. Duch Święty nieustannie ubogaca Kościół darami i charyzmatami oraz kieruje nimi tak, aby możliwe było wypełnienie jego misji wobec wszystkich narodów ${ }^{8}$. Tak oto wypełnia się misja Trzech Osób Boskich, której zamiarem było zbudowanie Kościoła celem zbawienia ludzi. Ów trynitarny wymiar Kościoła wyznacza istotę Kościoła i Jego stałą żywotność.

Zrozumienie zbawczej misji Kościoła wymaga odkrycia potrójnej prawdy - tak często przypominanej przez Jana Pawła II - o Kościele jako tajemnicy, wspólnocie i misji ${ }^{9}$. Kościół-tajemnica - czyli odniesienie do najgłębszej istoty Kościoła - wyrasta z misji zbawczej Trójcy Świętej, ale także sam jest owocem zbawienia. Kościół-wspólnota odsłania prawdę o budowaniu wspólnoty kościelnej dzięki temu, że zbawczy dar komunii Osób Boskich spotyka się z moralnym wysiłkiem człowieka. Kościół-misja odnosi się zaś do nakazu Jezusa Chrystusa, by Jego dzieło zbawienia było kontynuowane, oczywiście mocą obecnego w Kościele Boga, a to oznacza, że nadal jest uobecniane dzieło zbawcze Ojca, Syna i Ducha Świętego ${ }^{10}$.

\section{ODKRYCIE KOŚCIOLA-TAJEMNICY}

W swej eklezjologii Jan Paweł II zarówno początek, jak i misję Kościoła, ukazuje w perspektywie „tajemnicy”, podkreślając znacznie Bożego obdarowania życiem Trójcy Świętej. Kościół ,jest

8 Por. KKK 768. Por. także: S. N a g y, Kościót Ojca, Syna i Ducha Świętego, dz. cyt., s. 117.

9 Por. A.F. D z i u b a, Chrześcijańska odpowiedzialność roku 2000, w: G. W i t a s z e k (red.), Tertio millennio adveniente. U progu trzeciego tysiaclecia, Lublin 2000 s. 473.

${ }^{10}$ Charakterystyczną jest rzeczą, że do tego potrójnego wymiaru widzenia Kościoła Papież odnosi także posłannictwo poszczególnych stanów w Kościele. W tej potrójnej, tak widzianej eklezjologii, Ojciec św. interpretuje powołanie świeckich (Christifideles laici), kapłanów (Pastores dabo vobis) i osób konsekrowanych (Vita consecrata). 
tajemnicą, albowiem miłość i życie Ojca, Syna i Ducha Świętego są zupełnie bezinteresownym darem dla tych, którzy narodzili się z wody i z Ducha (por. J 3, 5) i zostali wezwani do przeżywania, a także wyrażania i przekazywania w dziejach (misja) jedności samego Boga""11. Papież przywołując przypowieść o krzewie winnym uzasadnia tajemniczą więź, jaka łączy ochrzczonych z Bogiem Trójjedynym. Dar nowego życia umożliwia im ,tajemnicze uczestnictwo w miłości, która łączy w jedno Ojca, Syna i Ducha Świętego" i sprawia, że jest to „komunia żywa i ożywiająca"

Ma tu miejsce przedziwna wymiana darów, która sprawia, że nie tylko człowiek zostaje włączony w życie Boga, ale także Bóg zamieszkuje w człowieku, czyniąc go „świątynią Bożą”. To oznacza, że „człowiek-osoba jest w Kościele mieszkaniem Boga-Trójcy, a cały Kościół, składający się z osób, w których mieszka Trójca Święta, jest jako całość mieszkaniem, świątynią Trójcy Świętej”"13. Komunia Trójcy Osób jest wzorem, źródłem i celem jedności chrześcijan, ta właśnie „,jedność stanowi tajemnicę Kościoła”. Dlatego źródłem wszystkich wysiłków zmierzających do budowania jedności Kościoła jest jedność samego Boga.

Tajemnica Kościoła odsłania wprost świętość Kościoła, gdyż świętość Boga-Trójcy jest też źródłem świętości Kościoła oraz wszelkiej świętości w Kościele ${ }^{14}$. Wskazanie źródła świętości Kościoła prowadzi do odkrycia wezwania i daru świętości dla każdego. Powołanie

${ }^{11}$ ChL 8. Por. PDV 12. Por. także: T. Š p i d l i k, La persona come partecipazione all'amore trinitario, w: A partire dalla persona. Una teologia per la nuova evangelizzazione, Lipa - Centro Aletti Roma 1994, s. 15-18.

12 ChL 18. „Od narodzin aż do historycznego końca i odwiecznego przeznaczenia Kościół odnajduje swą istotę i czerpie życie z Trójcy Świętej”. J a n P a w e 1 II, Katecheza: Kościól a tajemnica Trójcy Przenajświętszej (9.10.1991) nr 1. w: Katechezy Ojca Świętego..., dz. cyt., s. 45.

13 J a n P a w eł II, Katecheza: Kościól a tajemnica Trójcy Przenajświętszej nr 6, w: Katechezy Ojca Świętego..., dz. cyt., s. 47.

14 „Ponowne odkrycie Kościoła jako ‘tajemnicy', czyli jako ‘ludu zjednoczonego jednością Ojca i Syna, i Ducha Świętego', musiało doprowadzić także do ponownego odkrycia jego 'świętości', pojmowanej w podstawowym znaczeniu jako przynależność do Tego, który jest w najgłębszym sensie Święty, 'po trzykroć 
do świętości nie jest jedynie nakazem moralnym, lecz niezbywalnym wymogiem tajemnicy Kościoła, albowiem jest to ,pierwsze i podstawowe powołanie, które Ojciec w Jezusie Chrystusie i przez Ducha Świętego kieruje do każdego z nich, powołanie do świętości, czyli do doskonałości w miłości”'15. Uczestnictwo w świętości Kościoła zobowiązuje do osiągania świętości i doskonałości każdego stanu w Kościele. Dlatego wzajemne świadectwo świętości osób konsekrowanych, kapłanów i świeckich, pomaga w pełnym przeżywaniu ich udziału w tajemnicy Chrystusa i Kościoła ${ }^{16}$.

\section{DOŚWIADCZENIE KOŚCIOLA-KOMUNII}

Dokumenty soborowe dotyczące istoty Kościoła doprowadziły do wyakcentowania eklezjologii komunii, zarówno w samym rozumieniu Kościoła jako komunii, jak i w jej urzeczywistnianiu. Ta przedziwna rzeczywistość Kościoła-komunii zajmuje centralne miejsce w tajemnicy Bożego planu zbawienia ${ }^{17}$. Kościół-komunia mający swe źródło w komunii miłości Trójjedynego Boga oznacza zjednoczenie wierzących z Bogiem przez Chrystusa w Duchu Świętym. Ze strony człowieka owo zjednoczenie dokonuje się w słowie Bożym i sakramentach, zwłaszcza sakramentach inicjacji chrześcijańskiej. Jednak dar kościelnej komunii wymaga wolnej odpowiedzi człowieka, a świadomość daru winna budzić poczucie odpowiedzialności za tworzenie pełniejszej komunii ${ }^{18}$.

Święty' (por. Iz 6,3)". J a n P a w e ł II, List apostolski Novo millennio advenientes (dalej: NMI), nr 30.

15 J a n P a w e $\nmid$ II, Adhortacja apostolska Christifideles laici (dalej: ChL), nr 16.

16 Por. Jan Paweł II, Adhortacja apostolska Vita consecrata (dalej: VC), nr 33 .

17 Por. ChL 19; Kongregacja Nauki Wiary, List do biskupów Kościoła katolickiego o niektórych aspektach Kościoła pojętego jako komunia Communionis notio (28.05.1992) nr 1. w: Z. Z i m ow s k i, J. K ról i k ow s k i (red.),W trosce o petnie wiary. Dokumenty Kongregacji Nauki Wiary 1966-1994, Tarnów 1995, s. 390.

18 Por. Kongregacja Nauki Wiary, List Communionis notion, nr 4, s. 391-392. 
Odpowiedzialność za kościelną komunię wymaga rozwoju świadomości i duchowości: „zmysł kościelnej komunii, rozwijając się w duchowość komunii, kształtuje sposób myślenia, mówienia i działania, który sprawia, że Kościół rozrasta się w głąb i wszerz"19. W tym duchu Jan Paweł II wzywa na progu trzeciego tysiąclecia, aby krzewić duchowość komunii i „czynić Kościół domem i szkołą komunii”20. Duchowość komunii wskazuje, przy zachowaniu jedności z Trójjedynym Bogiem, na uzdolnienie i zobowiązanie do tworzenia więzi braterskich we wspólnocie Kościoła. Istotne jest jednak podkreślenie owej tajemnicy więzi ludzkich w Kościele opartych na dynamicznej jedności z Bogiem: ,życie braterskie ma odzwierciedlać głębię i bogactwo tej tajemnicy, tworząc ludzką przestrzeń zamieszkałą przez Trójcę Przenajświętszą, która w ten sposób rozlewa w historii dary komunii, właściwe dla trzech Boskich Osób"21. Uczestnictwo w trynitarnej komunii daje moc przemiany ludzkich relacji i tworzy nowy typ solidarności. Budowanie komunii Kościoła, opartej na komunii miłości z Trójjedynym Bogiem, sprawia, że „właśnie budując tę komunię miłości, Kościół objawia się jako 'sakrament', czyli jako 'znak i narzędzie wewnętrznego zjednoczenia z Bogiem i jedności całego rodzaju ludzkiego"”22.

Komunii Kościoła nie da się więc wyjaśnić wyłącznie z punktu widzenia socjologicznego i psychologicznego, jest bowiem rzeczywistością nadprzyrodzoną. Podstawą więzi braterskich jest więź Ducha Świętego, który jest źródłem jedności w Kościele i jedności Kościoła. Warto zauważyć, że komunia Kościoła nie oznacza jednolitości, ponieważ w Kościele istnieje różnorodność charyzmatów i stanów życia ${ }^{23}$. Owa jedność i różnorodność ludzkich powołań ma

$19 \mathrm{VC} 46$.

20 NMI 43.

${ }^{21}$ VC 41. Por. J. N a g ó r n y, Moralność chrześcijańska. Życie z Chrystusem $i$ w Chrystusie we wspólnocie Kościoła, w: Katechizm Kościoła Katolickiego. Wprowadzenie, dz. cyt., s. 188-192.

22 NMI 42.

${ }^{23}$ Por. VC 4. Ojciec św. stwierdza: ,Jeden i ten sam Duch stanowi zawsze dynamiczną zasadę jedności i różnorodności Kościoła i w Kościele“ (ChL 20). 
swe uzasadnienie w Trójjedynym Bogu: „niewątpliwie jedność Kościoła odzwierciedla jedność Bóstwa, ale jednocześnie czerpie swą żywotność z troistości Ojca, Syna i Ducha Świętego, jej wyrazem jest różnorodność i bogactwo życia kościelnego. Jedność przejawia się w wielorakich formach życia"24. Kościelna wspólnota jawi się jako jedność „organiczna”, analogicznie do jedności ludzkiego ciała. Wspólnota ta charakteryzuje się „,W istocie współistnieniem wielorakich powołań i stanów, tajemnic, charyzmatów i zadań, które, choć różne, są w stosunku do siebie komplementarne"25.

Kościół jako organiczna komunia jest wielkim darem Ducha Świętego, który ludzi zjednoczonych we wspólnocie ubogaca darami hierarchicznymi i charyzmatycznymi. Dar Boga każdy wierzący ma nie tylko przyjąć z wdzięcznością, lecz także potwierdzić swoim zaangażowaniem w odpowiedzialność za Kościół. Dlatego posługi i charyzmaty, jako dary Ducha Świętego, są uzdolnieniem i zobowiązaniem do budowania Chrystusowego Ciała i pełnienia jego kościelnej misji w świecie. Chryzmaty otrzymane we wspólnocie mają służyć wspólnocie i dlatego powinny być przyjęte zarówno przez tych, którzy je otrzymują, jak i przez wszystkich pozostałych członków Kościoła ${ }^{26}$.

Kościół-komunia łączy w sobie różne powołania i stany życia: kapłanów, zakonników i świeckich, czyniąc ich podmiotem komunii Kościoła. Choć odmienny jest rodzaj ich powołania służą oni komplementarnie jedności Kościoła. W adhortacjach poświęconych tym powołaniom i stanom życia Papież podkreśla, że tajemnica Kościoła, jako tajemnica komunii trynitarnej, nacechowanej przez wymiar misyjny, pozwala odkrywać na nowo tożsamość poszczególnych powołań i odpowiadającą im służbę dla Kościoła ${ }^{27}$. Ich współpraca

24 J a n P a w eł II, Katecheza: Kościół a tajemnica Trójcy Przenajświętszej nr 4, w: Katechezy Ojca Świętego..., dz. cyt., s. 46.

${ }^{25} \mathrm{ChL} 20$. Por. J a n P a w e $\nmid$ II, Adhortacja apostolska, Ecclesia in Africa (dalej: EA), nr 20.

26 Por. ChL 21 i 24.

27 Por. Ja n P aw e ł II, Adhortacja apostolska Pastores dabo Vobis (dalej: PDV), nr 12, ChL 15, VC 29. Jan Paweł II podkreśla znaczenie świadectwa: „komunia powinna być wyraźnie widoczna w relacjach między biskupami, kapłanami 
w Kościele wymaga nie tylko poczucia własnej tożsamości, ale także tożsamości innych, czyli poznania i uznania różnych powołań, darów i charyzmatów ${ }^{28}$. Dlatego każdemu powołaniu powinna towarzyszyć stała formacja, pogłębiająca świadomość tworzenia braterskiej społeczności Kościoła na fundamencie komunii trynitarnej ${ }^{29}$.

Wówczas życie w komunii Kościoła staje się znakiem dla świata i zyskuje wymiar misyjny. Na ów dynamizm komunii Kościoła wskazał Papież mówiąc, że „komunia rodzi komunię i w samej swej istocie przyjmuje kształt komunii misyjnej" ${ }^{30}$. Odkrycie tajemnicy Kościoła i doświadczenie kościelnej komunii prowadzi więc wprost do uznania misyjności Kościoła. Jeśli się zagubi tę tajemnicę, to nowa ewangelizacja zostanie sprowadzona do ideologii. Podobnie jeśli zabraknie świadectwa kościelnej komunii, to wówczas nieodzowny element świadectwo chrześcijańskie - nie będzie dynamizował ewangelizacji. Misja Kościoła, a więc także nowa ewangelizacja, jest uwarunkowana wejściem w tajemnicę Kościoła i doświadczeniem komunii.

\section{ZADANIA KOŚCIOŁA-MISJI}

Rozważania dotyczące komunii kościelnej są wielkim znakiem obecności Chrystusa Zbawiciela w świecie, jednak ona sama pobudza do bezpośredniej działalności apostolskiej i misyjnej Kościoła. Dlatego Jan Paweł II wskazał na wzajemną zależność komunii i misji mówiąc, że „komunia jest równocześnie źródłem misji: komunia jest misyjna,

i diakonami, między duszpasterzami a całym Ludem Bożym, między duchowieństwem i zakonnikami, między stowarzyszeniami i ruchami kościelnymi” (NMI 45). Por. także: Por. W. S ł o m k a, Ku dojrzałości laikatu w Kościele i świecie. Studium wedtug adhortacji Jana Pawła II Christifideles laici. w: A.J. N o w a k, W. S ł o m k a (red.), Dojrzałość chrześcijańska. Homo meditans, t. 11, Lublin 1994, s. $124-126$.

28 PDV 59.

29 Por. PDV 74. Por. także: W. S ł o m k a, Duchowość kapłańska, Lublin 1996, s. $168-176$.

${ }^{30} \mathrm{ChL}$ 32. Por. T. Š p i d $1 \mathrm{i}$ k, La persona come partecipazione all'amore trinitario, dz. cyt., s. 24-27. 
misja zaś służy komunii”31. Misja Kościoła wynika z jego własnej natury, bowiem z woli Chrystusa jest on znakiem i narzędziem jedności rodzaju ludzkiego. Dlatego celem misji jest włączenie wszystkich ludzi w komunię trynitarną przeżywaną w Kościele. Ponadto Kościół czuje się „dłużnikiem” ludzkości, gdyż komunia, którą otrzymał w darze, jest przeznaczona dla wszystkich. Skoro więc wszyscy ludzie mają prawo poznać źródło i moc komunii międzyludzkiej, to znaczy, że Kościół jest posłany, a tę swą misję koncentruje i rozwija w nowej ewangelizacji.

Cały Kościół jest misyjny, czyli wszystkie jego stany są podmiotem komunii i zbawczej misji. Istniejąca odmienność powołań oznacza przygotowanie i pełnienie specjalnej misji, jednak pomimo tej różnorodności należy mówić o jedności misji Kościoła. Wszystkie stany, które współtworzą Kościół, powinny połączyć siły, zachować postawę współpracy i wymiany darów, by owocniej uczestniczyć w misji Kościoła ${ }^{32}$. Jak podkreśla Papież „w ostatnich latach pojawiła się potrzeba pełniejszego ukazania tożsamości różnych stanów życia, ich powołania i ich konkretnej misji w Kościele"33. Współpraca podmiotów tworzących Kościół jest także konieczna ze względu na współczesne wyzwania misyjne, które wymagają wspólnego wysiłku zarówno w sferze rozeznania, jak i działania. Udział w misji Kościoła jest zobowiązujący dla każdego, kto przez wiarę i sakramenty „stał się żywym członkiem Kościoła i aktywnym podmiotem jego zbawczej misji” ${ }^{34}$. Cały Kościół jest więc wezwaniem do uczestnictwa w misji ewangelizacyjnej, a konieczność tego zobowiązanie wynika $\mathrm{z}$ istotnego celu ewangelizacji, jakim jest zbawienie człowieka.

Kościół został wezwany do współdziałania z Bogiem w dziele zbawienia, jest bowiem historiozbawczą kontynuacją i narzędziem wewnątrztrynitarnej miłości Boga ${ }^{35}$. Kościół jako tajemnica zbawcza

${ }^{31}$ ChL 32. Por. VC 46. Por. także: N. C o n $\mathrm{r}$ a n, Duchowość misyjna, w: Kościót misyjny, dz. cyt., s. 147-155.

32 Por. VC 31; 54; ChL 23; NMI 46.

33 VC 4.

${ }^{34}$ CHL 3. Por. VC 74.

35 Por. J. S z y m i k, Chrześcijaństwo otwarte, w: Katechizm Kościoła Katolickiego. Wprowadzenie, dz. cyt., s. 241; A. N o w i c k i, Kościól-misterium, uczestnictwo 
odsłania nade wszystko więź Jezusa i Kościoła, Jezus jedyny Zbawiciel sam jest bowiem w Kościele, a Kościół jest w Nim, dlatego „pełnia tajemnicy zbawczej Chrystusa należy także do Kościoła”" Właściwie to sam Chrystus - jedyny Zbawiciel i Odkupiciel ludzkości, pełnia objawienia Bożego i centrum misterium zbawienia - nadal jest obecny i dokonuje zbawienia w Kościele, Ciele Mistycznym, którego jest Głową ${ }^{37}$.

Jedyność zbawczego pośrednictwa Jezusa Chrystusa wskazuje na jedyność zbawczą Jego Kościoła. Konsekwentnie prowadzi to do wniosku, że Kościół jest konieczny do zbawienia ${ }^{38}$. Bóg wybrał Kościół jako zwyczajną drogę swojego zbawczego działania, jako proste narzędzie zbawienia. Dlatego pośrednictwo zbawcze Kościoła wyraża się w przepowiadaniu Chrystusa i Jego dzieła zbawienia, które z kolei przyjęte przez wiarę prowadzi do świadomego korzystania z sakramentów, jako skutecznych znaków Bożego zbawienia ${ }^{39}$. Ów zbawczy charakter swego pośrednictwa Kościół przeżywał świętując Jubileusz Roku $2000^{40}$.

i postanie, w: M. B i s k u p, T. R e r o ń (red.), W kręgu chrześcijańskiego orędzia moralnego. Księga Jubileuszowa poświęcona ks. prof. Antoniemu Młotkowi, Wrocław 2000 s. 314-316.

36 Kongregacja Nauki Wiary, Deklaracja Dominus Jesus, (dalej: DJ), Rzym 2000 nr 16.

37 Por. DJ 16. Por. także: A. L e w e k, Nowa ewangelizacja $w$ duchu Soboru Watykańskiego II, t. 1, Katowice 1995, s. 318.

38 Por. DJ 20; J a n P a w e ł II, Katecheza: Jezus Chrystus-założyciel Kościoła nr 4, dz. cyt., s. 33; Por. także: S. N a g y, Chrystus żyjący w Kościele, dz. cyt., s. 79.

39 Od pośrednictwa zbawczego Kościoła należy odróżnić proces zbawczy, który chrześcijanin przeżywa zjednoczony z Chrystusem przez wiarę i życie sakramentalne, czyli realizuje się przy wsparciu pośrednictwa zbawczego Kościoła, ale jest dziełem łaski Bożej. Por. K. W i ę s y k, Głoszenie prawdy o Chrystusie przez lud kapłański integralnym warunkiem dynamicznego rozwoju wspólnoty Kościoła, w: E. Szczotok, A. Liskowacka (red.), Ewangelizacja w tajemnicy i misji Kościoła. Komisja Episkopatu Polski Duszpasterstwa Ogólnego. Program duszpasterski na rok 1994/95, Katowice 1994, s. 376-377.

40 „Wyraz 'Jubileusz’ mówi o radości [...] Kościół raduje się ze zbawienia. Do tej radości zaprasza wszystkich, stwarzając szczególne warunki po temu, ażeby zbawcze energie mogły stać się udziałem każdego" (TMA 16). 
Skoro więc Chrystus dokonuje zbawienia w Kościele i poprzez Kościół, którym jest Jego Mistyczne Ciało, to „droga zbawienia jest istotnie związana z Kościołem [...] Aksjomat ten oznacza, że ludzie, którzy wiedzą, iż Kościół został założony przez Boga za pośrednictwem Chrystusa, jako niezbędny, mają obowiązek do niego przystąpić i wytrwać w nim, aby uzyskać zbawienie"41. Wszyscy ci, którzy są świadomi, że droga zbawienia związana jest z Chrystusem, mają obowiązek trwać z Chrystusem w Kościele pamiętając, że w tym sensie poza Kościołem „nie ma zbawienia”42.

Stwierdzenie ,poza Kościołem nie ma zbawienia” oznaczają, że pełnia zbawienia pochodzi od Chrystusa, a dostępna jest przez pośrednictwo Kościoła. Z woli Chrystusa Kościół posiada wszystkie środki zbawienia, co więcej dostępne są one jedynie w Kościele ${ }^{43}$. Podkreślenie prawdy o zbawieniu w Kościele nie jest sprzeczne z powszechną wolą zbawczą Boga. Jak zaznacza Jan Paweł II, prawdy te nie wykluczają się, a wręcz uzupełniają; prawda o możliwości zbawienia w Chrystusie dla wszystkich ludzi jest dopełniona przez prawdę o konieczności Kościoła w porządku zbawienia ${ }^{44}$.

W posłudze ewangelizacyjnej pojawia się niekiedy problem zbawienia tych, którzy w sposób widzialny nie należą do Kościoła, skoro głoszona jest prawda, że poza Kościołem nie ma zbawienia ${ }^{45}$. Jan Paweł II, w duchu nauczania swoich poprzedników stwierdza, że dar zbawienia nie jest zarezerwowany tylko dla tych, „którzy w wyraźny sposób wierzą w Chrystusa i weszli do Kościoła. Jeśli zbawienie zostało przeznaczone dla wszystkich, musi ono być dane

${ }^{41}$ J a n P awe $\nmid$ II, Katecheza: Chrystus droga zbawienia nr 4, w: Katechezy Ojca Świętego..., dz. cyt., s. 489.

42 Tamże, s. 488.

43 Por. S. G ą d e c k i, Misyjna natura Kościoła, w: Ewangelizacja w tajemnicy i misji Kościoła, dz. cyt., s. 21; S, N a g y, Chrystus żyjący w Kościele, dz. cyt., s. 82.

${ }_{44}$ Por. J a n P a w e ł II, Encyklika Redemptoris missio (dalej: RMi) nr 9; DJ 20. Por. także: S. K a r o t e m p r e 1, Chrystologiczne i soteriologiczne podstawy misji, dz. cyt., s. 62 .

45 Por. KKK 846. 
konkretnie do dyspozycji wszystkich"6. Dlatego też Kościół prowadzi dialog zbawczy ze wszystkimi ludźmi według wskazania Pawła VI, który określił kręgi dialogu zbawienia: dialog ekumeniczny z braćmi odłączonymi, dialog z wyznawcami religii niechrześcijańskich oraz dialog z wszystkimi ludźmi dobrej woli, choćby byli niewierzącymi lub ateistami ${ }^{47}$.

Dlatego też Boży plan przewiduje drogę zbawienia również dla tych, którzy bez własnej winy nie znają Chrystusa, z zaznaczeniem, że okoliczności „,bez własnej winy” nie można zweryfikować ani ocenić za pomocą kryteriów ludzkich, trzeba ją pozostawić wyłącznie Bożemu osądowi ${ }^{48}$. Jeśli Kościół naucza o możliwości zbawienia tych, którzy do niego nie należą, to czyni to z zastrzeżeniem, że istnieje „tajemnicza więź” człowieka z Chrystusem i Kościołem, która jest konieczna do zbawienia. Kościół jest świadomy, że ,wiadomymi tylko sobie drogami może Bóg doprowadzić ludzi nie znających Ewangelii bez własnej winy do wiary koniecznej do zbawienia"49.

Możliwe jest więc zbawienie tych, którzy bez własnej winy nie znają Chrystusowej Ewangelii i Jego Kościoła, ale szczerym sercem szukają woli Bożej mocą prawego sumienia. W ten sposób poznana prawda wpływa na ich życie ,pod wpływem łaski”, czyli nie dochodząc do wyraźnego poznania Boga mogą wieść uczciwe życie, jednak „nie bez łaski" ${ }^{50}$. Jeśli każdy człowiek jest powołany do zbawienia, które wymaga współpracy z łaską, a życie uczciwe jest warunkiem tego zbawienia, to znaczy, że życie uczciwe wyrasta z łaski, choć człowiek może nie rozpoznawać wprost zbawczej obecności Boga w swoim życiu ${ }^{51}$.

${ }^{46}$ RMi 10. Por. Ja n P awe ł II, Katecheza: Chrystus droga zbawienia nr 1, dz. cyt., s. 487-488.

47 Por. KK 13; TMA 56. Por. także K. W o j t y ł a, Ewangelizacja współczesnego świata, Kraków 1975, s. 33.

48 Por. J a n P aw e ł II, Katecheza: Chrystus droga zbawienia nr 2, dz. cyt., s. $488-489$.

49 Sobór Watykański II, Dekret o działalności misyjnej Kościoła Ad gentes divinitus (dalej: DM) nr 7.

${ }^{50}$ Por. KK 16.

51 Por. J a n P aw eł II, Przekroczyć próg nadziei, Lublin 1995, s. 145. 
Istnieje także możliwość udzielenia łaski człowiekowi bez jego zewnętrznej przynależności do Kościoła, jednak zawsze w odniesieniu do niego ${ }^{52}$. Jan Paweł II mówi o „tajemniczym związku” takiego człowieka z Kościołem; wiąże się to ze zbawczą tajemnicą łaski. Tajemnicze działanie łaski nie zwalnia człowieka z wysiłku, dlatego „aby zbawcza łaska mogła działać, potrzebne jest przylgnięcie, współpraca, pozytywna odpowiedź na Boży dar: przylgnięcie to przynajmniej w domyśle — dotyczy Chrystusa i Kościoła. Dlatego też można również powiedzieć: sine Ecclesia nulla salus - 'bez Kościoła nie ma zbawienia’. Przylgnięcie do Kościoła - Ciała Mistycznego Chrystusa, choć ma charakter domyślny i tajemniczy, stanowi istotny warunek zbawienia" ${ }^{53}$. Błędem byłoby jednak ,,postrzeganie Kościoła jako jednej z dróg zbawienia, istniejącej obok innych, to znaczy równolegle do innych religii, które miałyby uzupełniać Kościół" ${ }^{34}$. Choć w innych religiach istnieją elementy religijności pochodzące od Boga, to jednak trudno im przypisać zbawczą skuteczność, a dodatkowo niektóre obrzędy obciążone przesądami stanowią wręcz przeszkodę do zbawienia.

Uznając istnienie tajemniczych dróg Bożego planu zbawienia wobec tych, którzy „bez własnej winy” nie należą do Kościoła, trzeba podkreślić, że „te drogi nie mogą być powodem redukowania lub porzucania działalności misyjnej" 55 . Wprost przeciwnie, odpowiedzialność za życie i zbawienie innych zobowiązuje do aktywności misyjnej, „bowiem ten, kto nie zna Chrystusa, choć bez własnej winy, żyje w ciemnościach i duchowym niedostatku, co często pociąga

52 Por. RMi 10.

53 J a n P awe $\nmid$ II, Katecheza: Chrystus droga zbawienia nr 4, w: Katechezy Ojca Świętego..., dz.cyt., s. 490.

${ }^{54}$ DJ 21. Niektórzy uznając działanie Ducha Świętego wobec ludzkości przez sianie ,zarodków Słowa” domagają się dwu dróg zbawienia: jedna w Jezusie Chrystusie dla tych, którzy w Niego wierzą i druga w Duchu Świętym, który działa w innych kulturach i religiach. Por. T. F e d e r i c i, Pneumatologiczne podstawy misji, s. 79-82.

${ }_{55}$ J a n P a w eł II, Katecheza: Cel misyjnej działalności (10.05.1995) nr 3, w: Katechezy Ojca Świętego..., dz.cyt., s. 482. 
za sobą negatywne skutki w wymiarze kulturowym i moralnym. Działalność misyjna Kościoła może zapewnić mu warunki pełnego rozkwitu zbawczej łaski Chrystusa, umożliwiając pełne i świadome przyjęcie orędzia wiary oraz czynne uczestnictwo w życiu kościelnym w sakramentach" 56 .

W ten sposób odsłania się zbawczy fundament nowej ewangelizacji. Ma on swoje źródło i oparcie w zbawczym planie Boga, który urzeczywistnia się w Bogu Ojcu przez Syna w Duchu Świętym, a znajduje swe przedłużenie w zbawczej misji Kościoła. Ta eklezjologiczna perspektywa zarówno zbawienia, jak i dzieła nowej ewangelizacji prowadzi do stwierdzenia, że Kościół - będąc narzędziem zbawienia - jest jednocześnie podmiotem wszelkiej ewangelizacji, a więc także nowej ewangelizacji.

\section{Streszczenie}

Zrozumienie zbawczej misji Kościoła wymaga odkrycia potrójnej prawdy o Kościele jako tajemnicy, wspólnocie i misji. Kościół-tajemnica wyrasta z misji zbawczej Trójcy Świętej, ale także sam jest owocem zbawienia. Kościół-wspólnota odsłania prawdę o budowaniu wspólnoty kościelnej dzięki temu, że zbawczy dar komunii Osób Boskich spotyka się z moralnym wysiłkiem człowieka. Kościół-misja odnosi się zaś do nakazu Jezusa Chrystusa, by Jego dzieło zbawienia było kontynuowane, oczywiście mocą obecnego w Kościele Trójjedynego Boga. Kościół jest nie tylko wspólnotą zbawionych w Chrystusie, ale także nadprzyrodzonym miejscem udzielania innym zbawczej łaski Chrystusa-Zbawiciela. Dzięki trynitarnej komunii Ojca, Syna i Ducha Świętego Kościół jest narzędziem zbawienia człowieka.

\section{The Responsibility of the Church for the Gift of Salvation Summary}

Understanding the salvific mission of the Church requires the discovery the triple truth about the Church as a mystery, communion and mission. Church-mystery

\footnotetext{
56 Tenże, Katecheza: Chrystus droga zbawienia nr 5, dz. cyt., s. 490-491.
} 
grows out of the salvific mission of the Holy Trinity but also he is the fruit of salvation. Church-community reveals the truth about the building of the ecclesial community thanks to the salvific gift of communion of Divine Persons meets with moral human effort. Church-mission concerns to the command of Jesus Christ to His work of salvation was continued - by the power of Holy Trinity present in the Church. The Church is not only the community of the redeemed in Christ, but also is the place to giving other people salvific grace of Christ-Saviour. The Church is the instrument of the salvation of man by the Trinitarian communion of Father, Son and Holy Spirit.

\section{Bibliografia:}

Sobór Watykański II, Dekret o działalności misyjnej Kościoła Ad gentes divinitus, Sobór Watykański II, Konstytucje - Dekrety - Deklaracje, Wyd. 3. Poznań 1986 s. 436-474.

Jan Paweł II, Adhortacja apostolska Ecclesia in Africa, Watykan 1995.

Jan Paweł II, Adhortacja apostolska Christifideles laici, Watykan 1988. Jan Paweł II. Adhortacja apost. Pastores dabo vobis. Watykan 1992.

Jan Paweł II, Adhortacja apostolska Vita consecrata, Watykan 1996.

Jan Paweł II, Encyklika Redemptoris mission, Watykan 1990.

Jan Paweł II, Katechezy Ojca Świętego Jana Pawła II. Kościół, Kraków-Ząbki 1999. Jan Paweł II, List apostolski Novo millennio advenientes, Watykan 2001.

Jan Paweł II, Przekroczyć próg nadziei, Lublin 1995.

Katechizm Kościoła Katolickiego, Poznań 1994.

Kongregacja Nauki Wiary, List do biskupów Kościoła katolickiego o niektórych aspektach Kościola pojętego jako komunia Communionis notio (28.05.1992), w: Z. Zimowski, J. Królikowski (red.), $W$ trosce o petnię wiary. Dokumenty Kongregacji Nauki Wiary 1966-1994, Tarnów 1995.

Kongregacja Nauki Wiary, Deklaracja Dominus Jesus, Rzym 2000.

Contran N., Duchowość misyjna, w: Kościót misyjny. Podstawowe studium misjologii, S. Karotempler (red.) A. Halemba (red. Pol. Wyd.), (tłum.) R. Dziura, A. Halemba. Warszawa 1997, s. 147-155.

Dziuba A.F., Chrześcijańska odpowiedzialność roku 2000, w: G. Witaszek (red.), Tertio millennio adveniente. U progu trzeciego tysiaclecia, Lublin 2000, s. $463-491$. 
Federici T., Pneumatologiczne podstawy misji, w: Kościól misyjny. Podstawowe studium misjologii, S. Karotempler (red.) A. Halemba (red. Pol. Wyd.), (tłum.) R. Dziura, A. Halemba. Warszawa 1997, s. 73-83.

Gądecki S., Misyjna natura Kościoła, w: E. Szczotok, A. Liskowacka (red.), Ewangelizacja w tajemnicy i misji Kościoła. Komisja Episkopatu Polski Duszpasterstwa Ogólnego. Program duszpasterski na rok 1994/95, Katowice 1994, s. 11-27.

Karotemprel S., Chrystologiczne i soteriologiczne podstawy misji, w: Kościół misyjny. Podstawowe studium misjologii, S. Karotempler (red.) A. Halemba (red. Pol. Wyd.), (tłum.) R. Dziura, A. Halemba. Warszawa 1997, s. 57-71.

Lewek A., Nowa ewangelizacja w duchu Soboru Watykańskiego II, t. 1. Katowice 1995.

Nagórny J., Moralność chrześcijańska. Życie z Chrystusem i w Chrystusie we wspólnocie Kościoła, w: M. Rusecki, E. Pudełko (red.), Katechizm Kościoła Katolickiego. Wprowadzenie, Lubin 1995, s. 177-203.

Nagy S. Kościół Ojca, Syna i Ducha Świętego, w: M. Rusecki, E. Pudełko (red.), Katechizm Kościoła Katolickiego. Wprowadzenie, Lubin 1995, s. 116.

Nowicki A., Kościól-misterium, uczestnictwo i posłanie, w: M. Biskup, T. Reroń (red.), W kręgu chrześcijańskiego orędzia moralnego. Księga Jubileuszowa poświęcona ks. prof. Antoniemu Młotkowi, Wrocław 2000, s. 307-318.

Olejnik S., Teologia moralna fundamentalna, Włocławek 1998.

Olejnik S., Teologia moralna życia osobistego, Włocławek 1999.

Olejnik S., Teologia moralna życia społecznego, Włocławek 2000.

Olejnik S., W odpowiedzi na dar i powołanie Boże. Zarys Teologii moralnej, Warszawa 1979.

Słomka W., Duchowość kapłańska, Lublin 1996.

Słomka W., Ku dojrzałości laikatu w Kościele i świecie. Studium wedtug adhortacji Jana Pawła II Christifideles laici, w: A.J. Nowak, W. Słomka (red.), Dojrzałość chrześcijańska. Homo meditans, t. 11, Lublin 1994 s. 123-135.

Więsyk K., Głoszenie prawdy o Chrystusie przez lud kapłański integralnym warunkiem dynamicznego rozwoju wspólnoty Kościoła, w: E. Szczotok, A. Liskowacka (red.), Ewangelizacja w tajemnicy i misji Kościoła. Komisja Episkopatu Polski Duszpasterstwa Ogólnego. Program duszpasterski na rok 1994/95, Katowice 1994 s. 373-386. 